\title{
Analisis Penyambungan Distributed Generation Guna Meminimalkan Rugi-Rugi Daya Menggunakan Metode Particle Swarm Optimization (PSO)
}

\author{
Rosalind Fawnia Margeritha ${ }^{1}$, Rukmi Sari Hartati ${ }^{2}$, Ngakan Putu Satriya Utama
}

\begin{abstract}
Connection of Distributed Generation on distribution system influence the increasing power losses caused by DG connecting locations less precise. One of the ways to reduce the power losses is knowing the right location with optimization to DG connecting. Location of the optimization DG connecting on Bangli feeder to minimize power losses on distribution system in the Bangli feeders. From the results of power flow before connecting DG obtained power losses in the distribution system feeders Bangli of $160.120 \mathrm{~kW}$.

Optimization of DG connecting used Particle Swarm Optimization method. PSO method is selected because it can generate value (result) more stable according to fitness of input data. The result of applying PSO method to connecting DG in Bangli feeder distribution network system acquired location that generate minimum power losses at point 123 (Tembuku 14) with a losses of $108,870 \mathrm{~kW}$ or decrease power losses amounted to $51.2 \mathrm{~kW}$ if compared with a losses before DG connecting on Bangli feeders, and if compared to existing conditions of DG connecting at point 210 (Bangklet 1) in Bangli feeder loss-offs only decreased by $46.8 \mathrm{~kW}$. The results of the optimization DG connecting using PSO has a value decrease power losses that greater at around $32 \%$.
\end{abstract}

Intisari-Penyambungan Distributed Generation pada sebuah jaringan distribusi menimbulkan dampak meningkatnya rugi-rugi daya yang diakibatkan lokasi penyambungan DG yang kurang tepat. Salah satu cara yang dilakukan untuk mengurangi rugi-rugi daya adalah penentuan lokasi penyambungan DG yang tepat dengan optimasi. Optimasi lokasi penyambungan DG pada Penyulang Bangli bertujuan untuk meminimalkan rugi-rugi daya pada system distribusi di Penyulang Bangli. Dari hasil aliran daya awal diperoleh nilai rugi-rugi daya pada sistem distribusi Penyulang Bangli sebesar 160,120 kW.

Optimasi penyambungan DG ini menggunakan metode Particle Swarm Optimization. Metode PSO ini dipilih karena dapat menghasilkan nilai (hasil) yang lebih stabil sesuai dengan fitness yang dimasukkan. Hasil pengaplikasikan metode PSO pada sistem jaringan distribusi Penyulang Bangli, diperoleh lokasi penyambungan DG yang menghasilkan rugi-rugi daya minimum terdapat pada titik 123 (Tembuku 14) dengan rugirugi sebesar $108,870 \mathrm{~kW}$ atau terjadi penurunan rugi-rugi daya sebesar 51,2kW jika dibandingkan dengan kondisi eksisting penyambungan DG dititik 210 (bangklet 1) pada Penyulang Bangli rugi-ruginya hanya mengalami penurunan sebesar 46,8 kW. Hasil yang didapat dari optimasi penyambungan DG menggunakan metode Particle Swarm Optimization memiliki nilai penurunan rugi-rugi daya yang lebih besar yaitu sekitar $32 \%$.

\footnotetext{
${ }^{1}$ Mahasiswa, Jurusan Teknik elektro Fakultas Teknik Universitas Udayana, Jln. Kampus Bukit Jimbaran 80361 INDONESIA (tlp: 0361-555225; fax: 0361-4321982; e-mail: ocha.abank@gmail.com)

${ }^{2,3}$ Dosen, Jurusan Teknik Elektro Fakultas Teknik Universitas Udayana, Jln. Kampus Bukit Jimbaran 80361 INDONESIA (telp: 0361-703315; fax: 0361-703315; e-mail: rukmisari@unud..ac.id)
}

Kata Kunci- DG, Rugi-Rugi Daya, PSO, Lokasi terbaik

\section{PENDAHULUAN}

Energi listrik merupakan energi yang dibutuhkan untuk menunjang segala aktivitas manusia. Terlebih lagi saat ini permintaan konsumen terhadap energi listrik terus meningkat, yang tidak diimbangi dengan ketersediaan bahan bakar energi listrik tak terbarukan seperti fosil, batu bara dan minyak bumi. Jika sumber energi tak terbarukan yang tersisa digunakan secara kontinu dan dalam jumlah besar, maka sumber energi tersebut akan habis [1]. Oleh karena itu, saat ini diperlukan pengembangan sistem tenaga listrik yang menggunakan sumber energi terbarukan. Salah satu pembangkit yang menggunakan energi terbarukan adalah Distributed Generation. Distributed Generator (DG) merupakan jenis pembangkit listrik tersebar dalam skala kecil yang terletak pada sistem distribusi tenaga listrik [2]. Pada beberapa penelitian yang telah dilakukan sebelumnya untuk menentukan titik terbaik penyambungan Distributed Generation pada sebuah jaringan distribusi tersebut [3][4]. Salah satu Distributed Generation yang terdapat di Bali dan masih beroperasi adalah Pembangkit Listrik Tenaga Surya (PLTS) Kayubihi yang berada di kabupaten Bangli.

PLTS Kayubihi memiliki kapasitas sebesar 1 MW. Saat ini PLTS Kayubihi beroperasi hanya pada siang hari, hal ini dikarenakan PLTS Kayubihi ini belum dilengkapi dengan baterai sebagai saranan penyimpanan daya yang dapat digunakan sebagai sumber energi pada malam hari. PLTS Kayubihi pada saat ini tersambung dengan Busbar Bangklet 1.

Penyambungan PLTS Kayubihi pada jaringan distribusi Penyulang Bangli diperlukan sebab rugi-rugi yang dihasilkan pada Penyulang Bangli sebelum dipasang DG masih dikatakan cukup besar. Sehingga pemasangan DG ini diperlukan sebagai sumber daya tambahan untuk mengurangi besarnya rugi-rugi daya pada jaringan distribusi Penyulang Bangli yang cukup panjang. Permasalahan yang masih sering dihadapi dalam penyambungan DG adalah lokasi penyambungan DG yang belum optimal sehingga menyebabkan rugi-rugi daya yang besar. Lokasi penyambungan DG dapat dikatakan sudah optimal apabila rugi-rugi daya yang dihasilkan pada titik penyambungan sudah minimal serta level tegangan sangat terjaga. Salah satu metode yang dapat digunakan untuk mengetahui titik penyambungan DG terbaik adalah metode Particle Swarm Optimization (PSO). Metode ini digunakan untuk mendapatkan solusi terbaik dari semua solusi yang memungkinkan atau menemukan solusi yang berada dalam daerah yang mungkin.

Pada pembahasan ini akan dilihat dampak penentuan lokasi penyambungan PLTS Kayubihi terhadap penurunan rugi-rugi 
daya pada Penyulang Bangli. Perhitungan rugi-rugi daya sebelum penyambungan DG akan menggunakan metode Newton-Raphson. Selanjutnya dengan metode Particle Swarm Optimization akan diperoleh titik terbaik penyambungan DG (PLTS Kayubihi) yang menghasilkan rugi-rugi daya terkecil pada jaringan Penyulang Bangli.

\section{Distributed GENERATION}

Distribusi Generator (DG) adalah sebuah pembangkit energi listrik berskala kecil yang dapat menghasilkan daya antara $1 \mathrm{~kW}-10 \mathrm{MW}$, yang dihubungkan pada sistem distribusi dan biasanya dihubungkan pada bus yang langsung menyuplai pusat beban atau pada gardu induk distribusi. DG dibedakan menjadi dua macam, yaitu sebagai unit yang berfungsi untuk mengantisipasi apabila terjadi pemutusan dari suplay daya atau sebagai unit stand by dan berfungsi sebagai sebuah pembangkit tambahan yang dapat tersambung pada waktu terjadinya beban puncak atau peacking unit. Skema interkoneksi DG dapat dilihat pada Gambar 1.

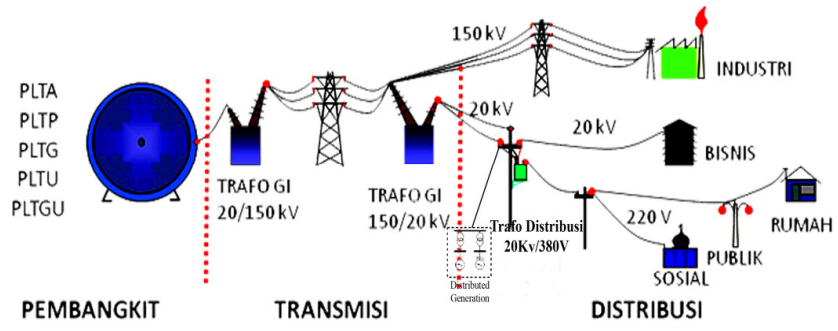

Gambar 1 : Penyambungan DG pada Sistem Jaringan Distribusi [5]

International Council on Large Electric Systems (CIGRE) dan Institute of Electrical and Electronic Engineers (IEEE) mendifinisikan Distributed Generation sebagai sebuah pembangkit yang menghasilkan energy listrik berkapasitas keci apabila dibandingkan dengan pembangkit konvensional dan dapat dipasangkan hampir pada setiap titik sistem tenaga listrik dengan kapasitas dibawah 10 MW. Distributed Generation yang terpasang dengan kapasitas daya kecil dipergunakan untuk melayani beban puncak yang terjadi pada jam-jam tertentu setiap harinya.

\subsection{Penerapan Metode Newton-Raphson pada Aliran Daya}

Terdapat beberapa metode yang dapat digunakan dalam penyelesaian studi aliran daya. Beberapa metode yang paling sering dipergunakan adalah metode Gauss-Seidel dan metode Newton-Raphson. Pada makalah kali ini, dipergunakan metode Newton-Raphson sebagai metode penyelesaian persamaan aliran daya. Metode Newton-Raphson ini dipilih, karena membutuhkan waktu yang lebih singkat untuk memperoleh nilai yang diinginkan sehingga proses iterasinya lebih sedikit. Metode ini merupakan penyempurnaan dari metode Gauss-Seidel, karena dapat mengatasi masalah ketelitian dan masalah banyaknya iterasi. Dalam penyelesaian analisis aliran daya dengan menggunakan metode NewtonRaphson, nilai daya aktif (Pp) dan daya reaktif (Qp) yang telah dihitung sebelumnya akan dibandingkan dengan nilai daya aktif dan daya reaktif yang sudah ditetapkan menggunakan persamaan 1 dan 2 [6].

Rosalind Fawnia: Analisis Penyambungan Distributed Generation ...

$$
\begin{aligned}
& \Delta P_{p}=P_{P^{\text {spec }}}-P_{P^{\text {calc }}} \\
& \Delta P_{p}=P_{P^{\text {spec }}}-\left|V_{p}\right| \sum_{q=1}^{n}\left|V_{q}\right|\left[G_{p q} \cos \left(\delta_{p}-\delta_{q}\right)+B_{p q} \sin \left(\delta_{p}-\delta\right)\right] \\
& p=1,2, \ldots, \mathrm{n} ; p \neq s \\
& \Delta Q_{p}=Q_{p}^{\text {spec }}-Q_{p}^{\text {calc }} \\
& \Delta P_{p}=P_{P^{\text {spec }}}-\left|V_{p}\right| \sum_{q=1}^{n}\left|V_{q}\right|\left[G_{p q} \cos \left(\delta_{p}-\delta_{q}\right)+B_{p q} \sin \left(\delta_{p}-\delta\right)\right] \\
& p=1,2, \ldots, \mathrm{n} ; p \neq s ; p \neq g
\end{aligned}
$$

Spec merupakan nilai yang telah ditentukan sedangkan calc merupakan nilai yang didapat berdasarkan perhitungan. Selama proses iterasi berlangsung terjadi perubahan pada daya aktif dan daya reaktif hingga mencapai nilai konvergen yang telah ditentukan [7].

\subsection{Konversi Satuan Per Unit}

Berdasarkan data yang diperoleh nilai $\mathrm{X}$ dan $\mathrm{R}$ masih belum dalam satuan p.u, sedangkan data yang dimasukkan ke dalam coding nilai $\mathrm{X}$ dan $\mathrm{R}$ harus dalam bentuk satuan p.u. Maka dari itu, perlu dilakukan penyederhanaan untuk masingmasing nilai $X$ dan $\mathrm{R}$ menggunakan persamaan 3,4,dan 5 yang dapat dilihat dibawah ini.

$$
\begin{aligned}
& \text { Base Voltage (V): } \frac{\text { Tegangan Bus }}{\sqrt{3}} \\
& \text { Base Current (I): } \frac{\text { KVA Dasar } 3 \emptyset}{\sqrt{3} \text { KV Dasar }} \\
& \text { Base Impedance (Z): } \frac{(\text { KV Dasar })^{2}}{\text { MVA Dasar } 3 \emptyset}
\end{aligned}
$$

Nilai X dan $\mathrm{R}$ dalam p.u digunakan sebagai data yang berfungsi sebagai masukan dalam coding yang akan diproses untuk mencari nilai rugi-rugi daya dan lokasi terbaik untuk menyambungkan DG pada Penyulang Bangli yang diolah menggunakan metode Particle Swarm Optimization (PSO).

\subsection{Penghitungan Rugi-Rugi Daya}

Pengoptimasian penyambungan DG ke Grid ini bertujuan untuk meminimalkan rugi-rugi daya yang dihasilkan guna mengoptimalkan daya yang dapat dihasilkan oleh DG yang terpasang pada penyulang tersebut. Dimana persamaan rugirugi daya yang dihasilkan dari penyulang tersebut dapat dilihat pada persamaan 8 yang diperoleh dari penurunan persamaan 6 dan persamaan 7 .

$$
P=i^{2} \cdot r
$$

$P=i^{2} \cdot r . l$

$$
P=\sum_{i=1}^{n} I_{a i}^{2} R_{i}+\sum_{i=1}^{n} I_{r i}^{2} R_{i}
$$

Dimana :

$\mathrm{P}=$ Daya

$\mathrm{I}_{\mathrm{ai}}=$ Arus aktif

$\mathrm{I}_{\mathrm{ri}}=$ Arus Reaktif

$\mathrm{R}=$ tahanan
)

(1)




$$
1=\text { panjang kabel }
$$

Dimana kendala yang didapat pada analisis kali ini adalah Voltage Profile, dimana dapat dilihat pada persamaan 9 [8].

$f_{v}=\frac{1}{N \sqrt{\sum_{j=1}^{j=N}\left(V_{n}-V_{j}\right)^{2}}}$

Dimana :

Fv : Profil Tegangan

$V n$ : Tegangan level

$V j$ : Tegangan pada bus

$\mathrm{N}$ : Jumlah bus yang bekerja

\section{METODOLOGI}

\section{A. Particle Swarm Optimization}

Particle Swarm Optimization merupakan sebuah metode optimasi yang berdasarkan pada swarm intelligence atau yang disebut algoritma behaviorally inspired yang dapat digunakan sebagai alternatif dari algoritma genetika. Dalam optimasi multivariable seperti PSO, kawanan dianggap memiliki ukuran tertentu dan posisi yang acak untuk setiap partikel dalam ruang multidimensi. Setiap partikel pada PSO dianggap memiliki 2 karakter, yaitu : posisi dan kecepatan. Masingmasing partikel bergerak dalam ruang multidimensi tertentu dan masing-masing partikel akan mengingat posisi terbaik yang sudah dilalui sebelumnya [9].

Setiap partikel yang terdapat dalam ruang multidimensi PSO akan menyampaikan titik terbaiknya kepada partikel lain, sehingga setiap partikel akan menyesuaikan posisi dan kecepatannya sesuai dengan informasi yang diterima mengenai posisi tersebut. Contohnya, adalah perilaku lebah dalam dalam kawanan [10]. Meskipun setiap lebah memiliki keterbatasan kecerdasan, lebah akan selalu mengikuti kebiasaan (rule), misalnya:

1. Posisi lebah dengan lebah lainnya tidak akan terlalu dekat.

2. Lebah akan terbang mengikuti arah lebah lainnya terbang.

3. Posisi lebah akan sesuai dengan posisi rata-rata lebah lainnya, sehingga menjaga jarak antar lebah dalam kawanan itu tidak terlalu jauh.

Sehingga perilaku suatu kawanan lebah berdasarkan pada penggabungan 3 faktor, yaitu :

1. Kohesi (terbang bersama)

2. Separasi (jangan terlalu berdekatan)

3. Penyesuaian (mengikuti arah yang sama)

Dalam program PSO ini akan menggunakan sejumlah bilangan yang akan digunakan sebagai calon lokasi penyambungan DG dan direalisasikan kedalam data. Berikut ini merupakan alur analisis data secara umum yang dilakukan dalam penelitian ini dapat dilihat pada Gambar 2.

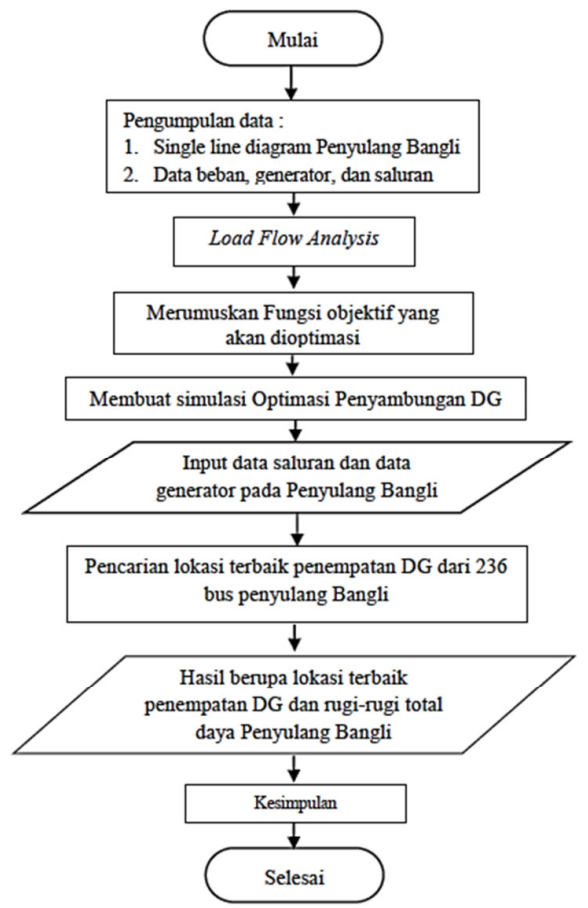

Gambar 2: Diagram Alur Penelitian

Langkah-langkah dari program Particle Swarm Optimization (PSO) dapat dilihat pada Gambar 3. Berikut adalah langkah yang akan dilakukan :

1. Menentukan ukuran swarm, nilai, dan kecepatan partikel secara acak.

2. Mengevaluasi fungsi tujuan dari masing-masing partikel.

3. Menentukan Pbest dan Gbest awal.

4. Menghitung kecepatan dari iterasi selanjutnya dengan menggunakan persamaan berikut :

$V_{j}(i)=\theta V_{j}(i-1)+c_{1} r_{1}\left[P_{\text {best } j}-X_{j}(i-1)\right]+c_{2} r_{2}\left[G_{\text {best } j}-X_{j}(i-\right.$

1)]

Dimana :

$\mathrm{i}=$ iterasi ke-.. .

$\mathrm{j}=1,2,3,4,5, \ldots . \mathrm{N}$

$r_{1}$ danr $_{2}=$ bilangan random

5. Menentukan posisi setiap partikel dari iterasi selanjutnya dengan persamaan :

$X_{j}(i)=X_{j}(i-1)+V_{j}(i)$

Dimana :

$\mathrm{Xj}$ : Posisi partikel pada iterasi berikutnya

$\mathrm{Vj}$ : Kecepatan pada iterasi berikutnya

6. Melakukan evaluasi terhadap fungsi tujuan dari iterasi berikutnya.

7. Memperbaharui nilai Pbest dan Gbest.

8. Melakukan pengecekan apakah solusi dari optimasi yang dijalankan sudah optimal atau belum. Jika sudah mendapatkan hasil optimal, maka proses algoritma akan berhenti, tetapi jika hasil yang didapat belum optimal maka proses akan diulangi kembali pada langkah nomor 4. 


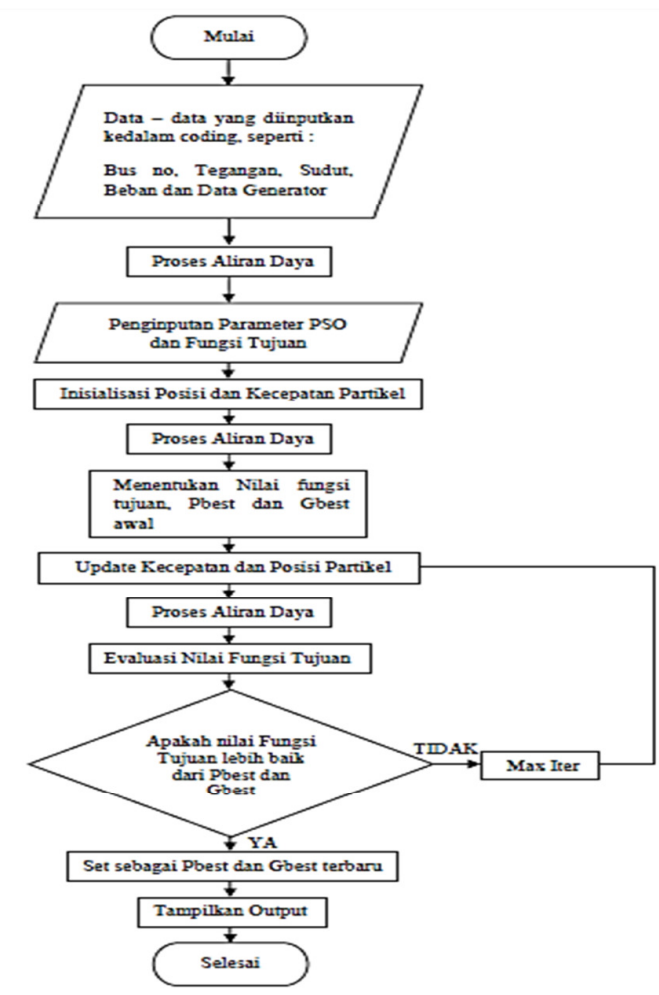

Gambar 3: Diagram Alur Pembuatan Program

Particle Swarm Optimazation (PSO) merupakan sebuah algoritma yang dapat digunakan untuk memecahkan masalah alokasi DG. Konsep utamanya adalah bahwa potensi solusi yang diterbangkan melalui hyperspace dan dipercepat menuju solusi yang lebih baik atau lebih optimal. Beberapa fitur PSO adalah adaptasi, respon beragam kedekatan, kualitas dan stabilitas. Berbeda dengan teknik komputasi lainnya, setiap partikel yang terdapat dalam PSO berhubungan dengan kecepatan yang dapat dapat dilihat pada persamaan 7 [11].

$v i(t)=u 1 \cdot k 1 \cdot v i(t-1)+u 2 \cdot k 2 \cdot(x b e s t i-x i)+$ u3. k3. (xbestg-xi) +u4.vacak

Dimana :

$\mathrm{X}_{\text {best }}=$ Posisi terbaik yang pernah dikunjungi

$\mathrm{g} \quad=$ Partikel yang kondisinya terbaik

$\mathrm{v}_{\text {acak }}=$ Vektor arah acak

$\mathrm{u} 1-\mathrm{u} 4=$ variable acak

$\mathrm{k} 1-\mathrm{k} 4$ = koefisien pengaruh masing-masing suku

Pada makalah ini, koefisien yang dicari dalam optimasi penyambungan DG adalah Xbest. Dimana Xbest adalah posisi terbaik yang dapat diperoleh selama running PSO, dan pada program PSO ini, akan dimasukkan sejumlah bilangan yang memiliki batasan yang digunakan sebagai calon lokasi DG.

\section{Optimasi MengGunakan Metode Particle Swarm OPTIMIZATION (PSO)}

A. Analisis Rugi Daya sebelum Penyambungan Distributed Generation

Berdasarkan data single line diagram yang diperoleh dari PT. PLN Distribusi Bali Timur untuk mengetahui besarnya rugi daya yang dihasilkan jaringan distribusi Penyulang Bangli sebelum adanya penyambungan DG, maka dilakukan analisis aliran daya menggunakan software pendukung. Load flow analis ini dilakukan dengan metode Newton-Raphson. Analisis aliran daya ini menggunakan masukan single line diagram, data panjang saluran, dan data beban serta generator yang terdapat pada Penyulang Bangli yang dapat dilihat pada Gambar 4 berikut.

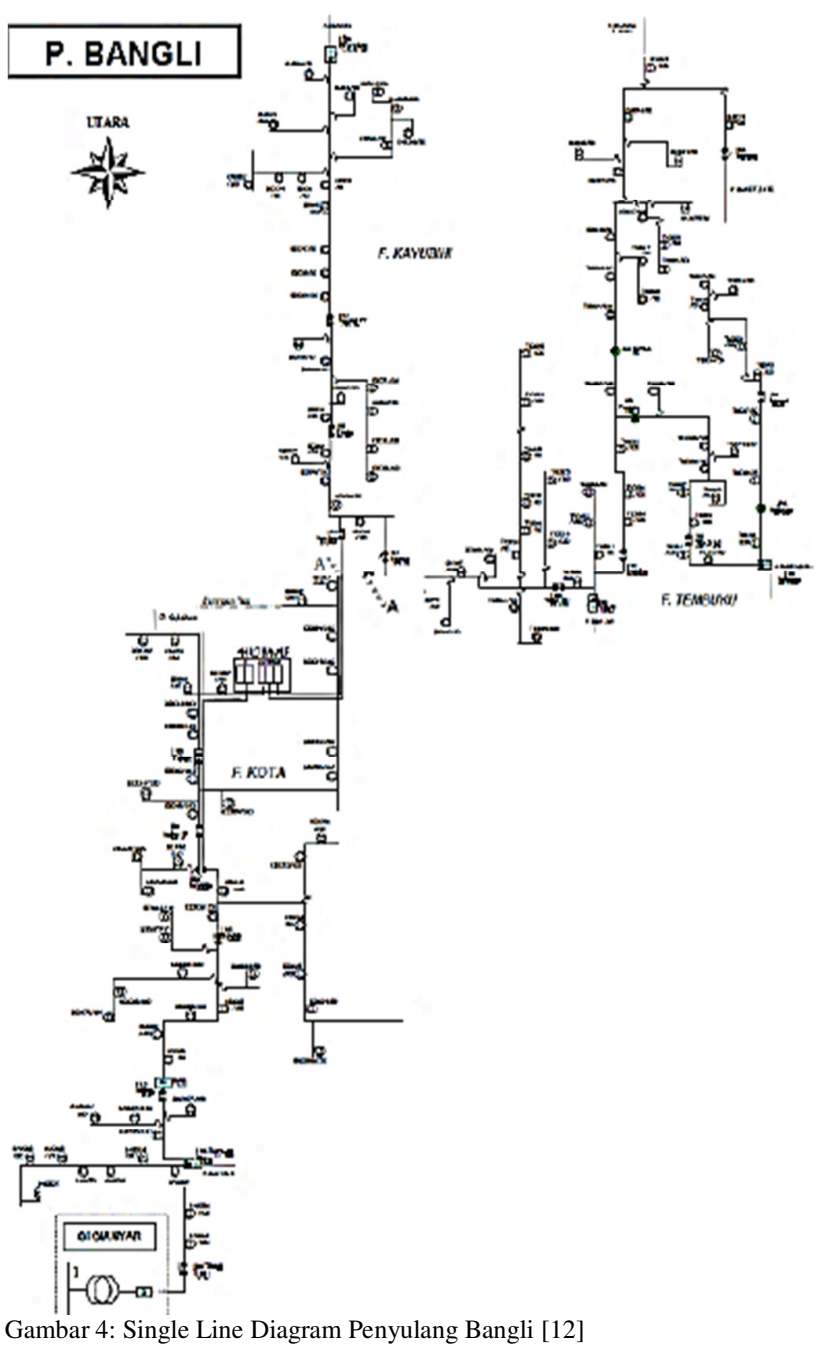

Data yang dimasukkan kedalam coding harus diproses dan diubah dahulu kedalam bentuk yang dapat dibaca dan diproses oleh program. Analisis ini dilakukan untuk mengetahui berapa rugi-rugi daya yang ada pada saluran Penyulang Bangli sebelum penyambungan oleh DG. Dimana analisis aliran daya tersebut memperoleh hasil pada Tabel 1 : 
TABEL I

DATA HASIL ANALISA ALIRAN DAYA PENYULANG BANGLI SEBELUM PENYAMBUNGAN DG

\begin{tabular}{|r|l|c|c|}
\hline No & Uraian & Nilai & Keterangan \\
\hline 1 & Total Daya & $3071 \mathrm{~kW}$ & GI Gianyar \\
\hline 2 & Rugi Daya & $160,120 \mathrm{~kW}$ & $5,3 \%$ dari total daya \\
\hline
\end{tabular}

Berdasarkan hasil perhitungan aliran daya, maka besar rugi daya yang dihasilkan pada jaringan distribusi Penyulang Bangli sebelum terpasang unit pembangkit tersebar jenis PLTS dengan kapasitas 1 MWp sebesar 160,120 kW.

B. Analisis Penyambungan Distributed Genertion menggunakan Metode Particle Swarm Optimization

Sistem distribusi Penyulang Bangli terdiri dari 1 pembangkit dan 236 bus distribusi. Pada makalah ini, diperlukan data seperti; penomoran bus, data beban, pembangkit, dan parameter saluran. Data beban yang dipergunakan memiliki beban total yang terpasang adalah 2.607MW dan 1.616MVAR. Setelah memperoleh data-data yang dipergunakan sebagai masukan data yang digunakan pada coding Particle Swarm Optimization (PSO) yang ditampilkan pada Tabel 2 berikut:

TABEL II

DATA BUS PENYULANG BANGLI [12]

\begin{tabular}{|l|l|l|l|l|l|l|}
\hline \multirow{2}{*}{$\begin{array}{l}\text { Bus } \\
\text { No. }\end{array}$} & \multirow{2}{*}{$\begin{array}{l}\text { Volt. } \\
\text { mag }\end{array}$} & \multirow{2}{*}{$\begin{array}{c}\text { Ang. } \\
\text { deg }\end{array}$} & \multicolumn{2}{|c|}{ LOAD } & \multicolumn{2}{c|}{ GENERATOR } \\
\cline { 4 - 7 } & & & MW & MVAR & MW & MVAR \\
\hline 1 & 1,050 & 0,0 & 0 & 0 & 3071 & 1830 \\
\hline 2 & 1,049 & 0,0 & 0 & 0 & 0 & 0 \\
\hline 3 & 1,048 & 0,0 & 0 & 0 & 0 & 0 \\
\hline 4 & 1,046 & 0,0 & 0,060 & 0,037 & 0 & 0 \\
\hline 5 & 1,044 & 0,1 & 0,047 & 0,029 & 0 & 0 \\
\hline 6 & 1,041 & 0,1 & 0 & 0 & 0 & 0 \\
\hline 7 & 1,037 & 0,2 & 0,016 & 0,010 & 0 & 0 \\
\hline 8 & 1,037 & 0,2 & 0,009 & 0,006 & 0 & 0 \\
\hline 9 & 1,036 & 0,2 & 0,054 & 0,033 & 0 & 0 \\
\hline 10 & 1,033 & 0,2 & 0,074 & 0,046 & 0 & 0 \\
\hline$\ldots$ & $\ldots$. & $\ldots$ & $\ldots$. & $\ldots$. & $\ldots$. & $\ldots$ \\
\hline 236 & 0,970 & 1,1 & 0,006 & 0,004 & 0 & 0 \\
\hline
\end{tabular}

Setelah memperoleh data masukan yang terdapat pada tabel diatas, selanjutnya data tersebut akan diolah kedalam bertık coding yang digunakan untuk mencari titik terbaik da proses optimasi. Maka diperoleh persamaan 12 y digunakan sebagai fungsi objektifnya.

Fitness $=\sum_{i=1}^{n} \sum_{j=1}^{n}\left(\alpha_{i j}\left(P_{i} P_{j}+Q_{i} Q_{j}\right)+\beta_{i j}\left(Q_{i} P_{j}-P_{i} Q_{j}\right)\right)$

$P_{i}$ dan $P_{j}=$ Daya aktif bus $\mathrm{i}$ dan $\mathrm{j}$

$Q_{i}$ dan $Q_{j}=$ Daya reaktif bus $\mathrm{i}$ dan $\mathrm{j}$

$r_{i j} \quad=$ Tahanan antara bus $\mathrm{i}$ dan $\mathrm{j}$

$V_{i}$ dan $V_{j}=$ Tegangan bus $\mathrm{i}$ dan $\mathrm{j}$

$\delta_{i}$ dan $\delta_{j}=$ Sudut bus i dan $\mathrm{j}$
Tujuan dari teknik penyambungan Distributed Generation adalah untuk meminimalkan kerugian total daya nyata. Secara matematis, fungsi tujuan dari rugi-rugi daya tersebut terdapat pada persamaan 13 .

$P_{L}=\sum_{k=1}^{n} \operatorname{Loss}_{k}$

Dengan batasan :

Batasan tegangan : $|V i|^{\min } \leq|V i| \leq|V i|^{\max }$

Setelah melakukan pengmasukan coding secara keseluruhan, maka berikutnya akan dibahas mengenai proses running program degan menggunakan GUI (Graphical User Interface) seperti yang terlihat pada Gambar 5.

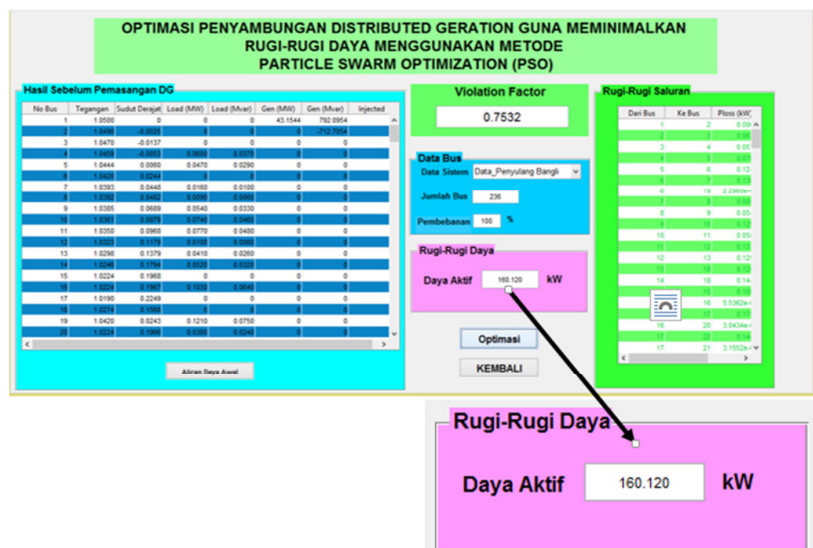

Gambar 5 : Tampilan data bus dan rugi-rugi daya Penyulang Bangli sebelum optimasi

Pada Gambar 5 terdapat tampilan aliran daya sebelum penyambungan DG, rugi-rugi persaluran, dan total rugi-rugi daya aktif. Dimana rugi-rugi daya total dari 236 bus yang terdapat pada Penyulang Bangli adalah sebesar 160,120kW, yang selanjutnya dari data yang ditampilkan akan diproses untuk mencari lokasi terbaik penyambungan DG sehingga dapat mengurangi rugi-rugi daya aktif. Pada saat proses optimalisasi berjalan, akan muncul grafik fungsi tujuan setiap iterasi. Dari Gambar 6 dapat dilihat bahwa fungsi tujuan tercapai pada lokasi ke-123. Banyaknya jumlah iterasi yang dibutuhkan pada setiap pengujian dapat berbeda-beda karenakan sistem optimasi PSO ini membangkitkan lokasi secara acak, yang dapat dilihat pada Gambar 6 berikut.

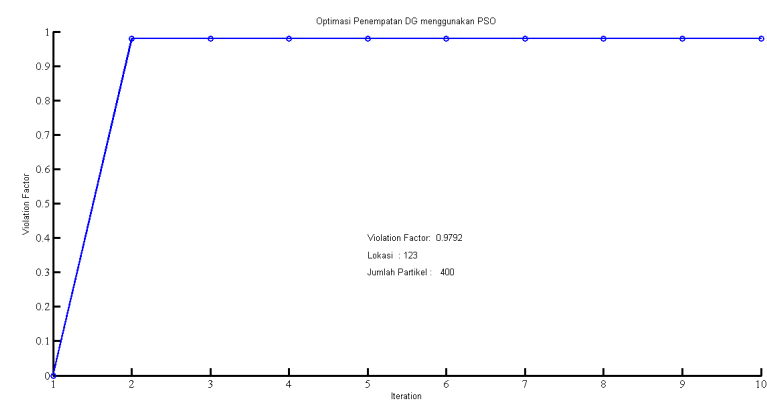

Gambar 6: Grafik Optimasi penempatan DG dengan menampilkan violation factor, lokasi penyambungan dan jumlah partikel yang digunakan. 
Seperti yang ditampilkan pada kurva pada Gambar 5, maka diperoleh hasil titik terbaik untuk menyambung Distributed Generation (DG) pada Penyulang terdapat pada bus 123 (Bus Tembuku 14). Hasil Running kurva tersebut selanjutnya akan ditampilkan menggunakan GUI pada Gambar 7, sehingga diketahui besar penurunan rugi-rugi daya sebelum dan sesudah dilakukan optimasi. Pada Gambar 7 tersebut, ditampilkan hasil rugi daya Penyulang Bangli setelah dilakukan optimasi Penyambungan DG, dimana optimasi tersebut menghasilkan nilai rugi daya yang minimum.

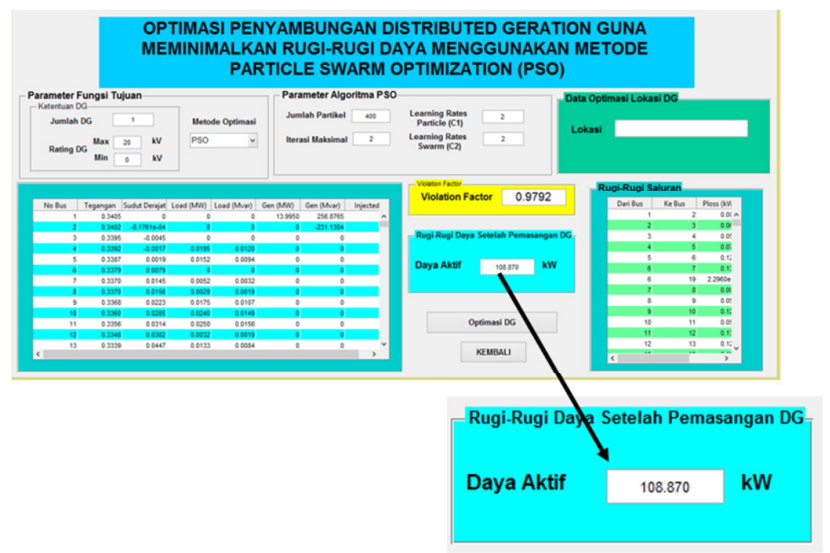

Gambar 7: Tampilan data bus dan penurunan rugi-rugi daya Penyulang Bangli setelah optimasi

Pada Gambar 7 diperoleh rugi-rugi daya setelah optimasi sebesar $108,870 \mathrm{~kW}$. Karakteristik metode PSO yang terdapat dalam program ini bersifat mencari nilai rugi daya terkecil. Partikel PSO hanya berpusat pada sebuah nilai tujuan (minimum losses) yang akan dicapai. Keberhasilan metode Particle Swarm Optimization (PSO) untuk menyelesaikan optimasi menurunkan rugi- rugi daya pada Penyulang Bangli ditunjukan pada Tabel 3 sebagai berikut :

TABEL III

PEMBUKTIAN PENURUNAN RUGI-RUGI DAYA SEBELUM DAN SESUDAH OPTIMASI

\begin{tabular}{|r|l|c|}
\hline No & Uraian & Nilai \\
\hline 1 & Rugi Daya Sebelum Penyambungan & $160,120 \mathrm{~kW}$ \\
\hline 2 & Rugi Daya Setelah Penyambungan DG & $108,870 \mathrm{~kW}$ \\
\hline \multicolumn{2}{|c|}{ Selisih Rugi-rugi Daya } & $\mathbf{5 1 , 2 5} \mathbf{~ k W}$ \\
\hline
\end{tabular}

Setelah dilakukan optimasi penyambungan DG dan memperoleh lokasi terbaik pemasangan DG serta dilakukan penyambungan DG pada titik 123 tersebut, maka diketahui pengurangan rugi-rugi daya sesudah optimasi penyambungan DG adalah sebesar 51,25 kW atau sekitar $32 \%$.

\section{KESIMPULAN}

Dari hasil pembahasan dan pengujian optimasi penyambungan DG guna meminimalkan rugi-rugi daya menggunakan metode Particle Swarm Optimization yang telah dilakukan maka dapat disimpulkan sebagai berikut :

1. Kondisi eksisting penyambungan DG pada Penyulang

Bangli saat ini terletak pada Bus Bangklet 1 atau pada titik 210 dengan rugi-rugi sebesar $113,4 \mathrm{~kW}$ dengan penurunan rugi-rugi sebesar $46,8 \mathrm{~kW}$.

2. Lokasi terbaik penyambungan DG pada Penyulang Bangli setelah dilakukan optimasi menggunakan program PSO terdapat pada titik 123 atau Bus Tembuku 14 dengan rugi-rugi sebesar 108,8 $\mathrm{kW}$.

3. Penyambungan DG pada Bus Tembuku 14 di Penyulang Bangli dapat menurunkan rugi-rugi daya sebesar $51,2 \mathrm{~kW}$ dari total rugi-rugi daya yang terjadi sebelum penyambungan DG sebesar 160,1 kW menjadi 108,8 kW.

4. DG yang terpasang pada Penyulang Bangli tidak dapat disambungkan pada Bus Tembuku 14 dikarenakan terbatasnya ketersedian lahan untuk pembuatan PLTS Kayubihi sebagai DG.

\section{REFERENSI}

[1] A. Lubis. 2007. Energi Terbarukan dalam Pembangunan Bekelanjutan. BPPT.

[2] E. K. Bawan. 2012. Dampak Pemasangan Distributed Generation Terhadap Rugi-Rugi Daya. Jurnal Ilmiah Foristek Vo.2, No.21, September.

[3] D. A. Putra. 2015. Analisis Rugi Daya pada Penyulang Bangli denganBeroperasinya PLTS Kayubihi. Jurnal Teknologi Elektro, Vol. 14, No. 1, Januari.

[4] I.M.G. Nusaman. 2015. Analisis Pengaruh Interkoneksi Distributed Generation (PLTSa Suwung) Terhadap Rugi - Rugi daya dan Keandalan Pada Penyulang Serangan. Jurnal Teknik Elektro, Vol. 14, No. 2. Juli-Desember.

[5] D. Marsudi. 2005. Pembangkit Energi Listrik. Jakarta: Penerbit Erlangga.

[6] M. A. Pai. 1979. Computer Techniques In Power System Anallysis. New Delhi: Tata Mc Graw - Hill Publising Company.

[7] Sulasno. 1993. Analisis Sistem Tenaga. Semarang: Badan Penerbit Universitas Diponegoro

[8] N. I. Luthfi, dkk. 2013. Optimasi Penempatan Distributed Generation pada IEEE 30 BUS Sistem menggunakan Bee Colony Algorithm. Jurnal Transient, Vol. 2, No. 3. I.P.S.

[9] Handika. 2016. Perbandingan Metode Extreme Learning Machine dan Particle Swarm Optimization Extreme Learning Machine untuk Peramalan Jumlah Penjualan Barang. Jurnal Teknologi Elektro, Vol. 15, No. 1, Januari-Juni.

[10] Febriansyah, dkk. -. Optimasi Kapasitas Pembangkit Tersebar Untuk Mengurangi Rugi Daya Aktif Menggunakan Particle Swarm Optimization dan Pengaruhnya Terhadap Indeks Kestabilan Tegangan.Jurnal Jurusan Teknik Elektro Universitas Diponegoro.

[11] A. K. Alrijadjis. 2010. Optimasi Kontroler PID Berbasis Particle Swarm Optimazation (PSO) Untuk Sistem Waktu Tunda.Jurnal Politeknik Elektronika Negeri Surabaya.

[12] PT. PLN (Persero) Distribusi Bali - Area Bali Timur. 2015. 